\title{
JC Virus Infection: An Expanding Spectrum of Neurological Disorders
}

Keywords: HIV, JC Virus, Granule Cell Neuronopathy, Demyelination

doi:10.1017/cjn.2018.32

Can J Neurol Sci. 2018; 45: 365-366

An article by Simon Grandjean Lapierre et $\mathrm{al}^{1}$ in this issue of the journal reports another case of JC virus granule cell neuronopathy, which was caused both by a known and a novel JC virus variant. It has now been 15 years since this disease was first described by Igor Koralnik et $\mathrm{al}^{2}{ }^{2}$ and it has been 60 years since E.P. Richardson, Jr., and others first described and named progressive multifocal leukoencephalopathy (PML). ${ }^{3}$ Progressive multifocal leukoencephalopathy is an opportunistic disease caused by reactivation of latent JC virus that causes infection of oligodendrocytes, resulting in demyelination; in addition, some astrocytes are altered and become enlarged with hyperchomatic nuclei resembling a malignant glioma. In 1965, Gabriele ZuRhein at the University of Wisconsin in Madison discovered the etiology by identifying virus-like particles within oligodendrocyte inclusion bodies using electron microscopy. ${ }^{4}$ Because the particles had a diameter of $39 \mathrm{~nm}$, she correctly postulated at the time that the disease was caused by a papovavirus, ${ }^{4}$ which derives its name from the first syllables of the main subvarieties: papilloma, the wart virus; polyoma, oncogenic properties; and vacuolating virus, which infects monkeys. Thereafter, this finding was soon confirmed by viral cultivation, and the virus was named JC virus after the initials of patient John Cunningham from whom the brain extract was derived. ${ }^{5} \mathrm{JC}$ virus causes a ubiquitous infection in over half of adults, and it is typically acquired during childhood. The virus causes a latent or persistent infection in the kidneys and lymphoid organs. However, only a small fraction of immunocompromised patients infected with JC virus actually develop PML. Progressive multifocal leukoencephalopathy was initially recognized in patients with lymphoproliferative disorders, and subsequently about $85 \%$ of cases occurred in patients with human immunodeficiency virus (HIV) infection. In the era of highly active antiretroviral therapy, the incidence of PML has decreased. ${ }^{6}$ Progressive multifocal leukoencephalopathy also occurs in patients receiving immunomodulatory therapies, including natalizumab, which is of particular concern to neurologists managing patients with multiple sclerosis. ${ }^{7}$

Although JC virus infection is predominantly associated with PML, a variety of other neurological diseases have been recognized to also be caused by JC virus infection. In 2003, JC virus was first reported to cause productive infection involving granule cell neurons in the cerebellum and is called JC virus granule cell neuronopathy. ${ }^{2}$ Patients present with dysarthria and appendicular, truncal, and gait ataxia, and brain imaging shows cerebellar atrophy. Shortly afterward, it was determined that the tropism for cerebellar granule cells was related to a JC virus variant with a small deletion in the VP1 capsid protein. ${ }^{8}$ In this issue of the journal, Lapierre et al ${ }^{1}$ report a patient with prominent cerebellar features without antibodies that are associated with encephalitis or paraneoplastic disorders, and with HIV infection and a positive polymerase chain reaction (PCR) virus assay for JC virus in the CSF. This patient had a JC virus granule cell neuronopathy, and viral DNA sequencing showed coinfection with a previously recognized JC virus variant associated with granule cell neuronopathy and also with a novel JC virus variant with different deletions in the $V P 1$ gene coding for the major capsid protein of the $\mathrm{JC}$ virus. Hence, it is now known that a variety of viral mutations affecting this viral protein may result in tropism for cerebellar granule cells and may clinically present a degenerative cerebellar disease phenotype.

Recently, another disease, a fulminant JC virus encephalopathy with progressive cognitive decline, aphasia, and seizures, was described in 2009, in which there was productive infection of cortical pyramidal neurons by JC virus. ${ }^{9}$ Interestingly, this patient showed JC virus with an agnogene deletion that resulted in a 10-amino-acid truncation of a peptide in a viral protein. ${ }^{10}$ This deletion has been found to impair expression of the VP1 structural protein and, hence, production of progeny virus. ${ }^{11}$ Another case was recently described in a kidney transplant recipient. ${ }^{12}$ In 2017 , JC virus meningitis was reported in a patient with recurrent infections who later developed lymphocytopenia and presented with cognitive and gait impairment with urinary incontinence and had communicating hydrocephalus. ${ }^{13}$ There was postmortem evidence of productive JC virus infection involving leptomeningeal and choroid plexus cells, ${ }^{13}$ and recent studies have shown that JC virus productively infects both choroid plexus epithelial cells and meningeal cells in vitro. ${ }^{14}$

The diagnosis of these neurological diseases is based on detection of JC virus DNA using PCR methods in cerebrospinal fluid (CSF) or immunohistochemical detection of JC virus antigen in brain biopsy specimens. JC virus variants have shown tropisms for a variety of neural cells types: oligodendrocytes and astrocytes in PML, cerebellar granule cells in granule cell neuronopathy, cortical pyramidal neurons in encephalopathy, and meningeal and choroid plexus cells in meningitis. All of these neurological diseases occur in an immunocompromised state either with or without associated HIV infection. One wonders how many other neurological diseases, especially in immunocompromised patients, may also be shown to be associated with mutations of JC virus. In the future, we should consider PCR assays for JC virus in the CSF for puzzling degenerative neurological diseases in immunocompromised patients and perhaps also in other patients without a recognized immunocompromised state.

\section{Disclosures}

The author does not have any conflicts of interest to disclose.

Received March 16, 2018. Date of Acceptance March 22, 2018. 
Alan C. Jackson Departments of Internal Medicine (Neurology) and of Medical Microbiology, University of Manitoba, Winnipeg

Manitoba, Canada

Correspondence to: A. C. Jackson, Health Sciences Centre GF-543, 820 Sherbrook Street, Winnipeg, MB, Canada R3A IR9 Email: ajackson2@hsc.mb.ca

\section{REFERENCES}

1. Lapierre SG, Dang X, Gilbert D, Lauzier S, Koralnik IJ, LeBlanc L. JC virus granule cell neuronopathy as AIDS presenting illness: a case report and review. Can J Neurol Sci. 2018. doi:10.1017/ cjn.2018.28.

2. Du Pasquier RA, Corey S, Margolin DH, et al. Productive infection of cerebellar granule cell neurons by JC virus in an HIV+ individual. Neurology. 2003;61:775-82.

3. Astom KE, Mancall EL, Richardson EP Jr. Progressive multifocal leuko-encephalopathy; a hitherto unrecognized complication of chronic lymphatic leukaemia and Hodgkin's disease. Brain. 1958;81:93-111.

4. ZuRhein GM, Chou SM. Particles resembling papova viruses in human cerebral demyelinating disease. Science. 1965;148:1477-9.

5. Padgett BL, Walker DL, ZuRhein GM, Eckroade RJ, Dessel BH. Cultivation of papova-like virus from human brain with progressive multifocal leucoencephalopathy. Lancet. 1971;1:1257-60.
6. Engsig FN, Hansen AB, Omland LH, et al. Incidence, clinical presentation, and outcome of progressive multifocal leukoencephalopathy in HIV-infected patients during the highly active antiretroviral therapy era: a nationwide cohort study. J Infect Dis. 2009;199:77-83.

7. Mills EA, Mao-Draayer Y. Understanding progressive multifocal leukoencephalopathy risk in multiple sclerosis patients treated with immunomodulatory therapies: a bird's eye view. Front Immunol. 2018;9:138.

8. Koralnik IJ, Wuthrich C, Dang X, et al. JC virus granule cell neuronopathy: a novel clinical syndrome distinct from progressive multifocal leukoencephalopathy. Ann Neurol. 2005;57:576-80.

9. Wuthrich C, Dang X, Westmoreland S, et al. Fulminant JC virus encephalopathy with productive infection of cortical pyramidal neurons. Ann Neurol. 2009;65:742-8.

10. Dang X, Wuthrich C, Gordon J, Sawa H, Koralnik IJ. JC virus encephalopathy is associated with a novel agnoprotein-deletion JCV variant. PLoS ONE. 2012;7:e35793.

11. Ellis LC, Norton E, Dang X, Koralnik IJ. Agnogene deletion in a novel pathogenic JC virus isolate impairs VP1 expression and virion production. PLoS ONE. 2013;8:e80840.

12. Bialasiewicz $\mathrm{S}$, Hart $\mathrm{G}$, Oliver $\mathrm{K}$, et al. A difficult decision: atypical JC polyomavirus encephalopathy in a kidney transplant recipient. Transplantation. 2017;101:1461-7.

13. Agnihotri SP, Wuthrich C, Dang X, et al. A fatal case of JC virus meningitis presenting with hydrocephalus in a human immunodeficiency virus-seronegative patient. Ann Neurol. 2014;76:140-147.

14. O'Hara BA, Gee GV, Atwood WJ, Haley SA. Susceptibility of primary human choroid plexus epithelial cells and meningeal cells to infection by JC virus. J Virol. 2018 (In press). 